\title{
From the Large Scale Expression Analysis of Lupus Nephritis to Targeted Molecular Medicine
}

\author{
Celine C Berthier ${ }^{1}$, Matthias Kretzler ${ }^{1}$ and Anne Davidson ${ }^{2 *}$
}

${ }^{1}$ Department of Internal Medicine, Nephrology, University of Michigan, Ann Arbor, MI 48109, USA

${ }^{2}$ Center for Autoimmunity and Musculoskeletal Diseases, Feinstein Institute for Medical Research, Manhasset, New York, NY 11030, USA

\begin{abstract}
Lupus nephritis (LN) is one of the most severe complications of systemic lupus erythematosus (SLE). Current treatments for LN lack sufficient efficacy as they do not necessarily target the LN responsible pathways and therapeutic responses vary widely in the patient population. LN mouse models have been useful in delineating disease pathogenesis and for testing novel therapies, but they do not entirely represent the events happening in human LN. This review describes how recently developed systems biology technologies can help to integrate current knowledge with large scale experimental data to generate new hypotheses and insight into the regulatory events occurring in LN.
\end{abstract}

Keywords: Systems biology; SLE; Nephritis; Mouse models; Human

\section{The Challenge of Lupus Nephritis}

Systemic lupus erythematosus (SLE) is a heterogeneous autoimmune disease which affects 1 in 2000 individuals in the United States of whom $\approx 90 \%$ are women [1]. It is characterized by the production of autoantibodies to nuclear antigens and affects multiple organs and tissues [1]. Inflammation of the kidney is one of the most severe manifestations of SLE and is characterized by renal deposition of autoantibodies and complement, production of cytokines/chemokines, activation and recruitment of inflammatory cells, and microvascular and parenchymal damage [2,3]. Despite advances in effective immunosuppressive therapies for many autoimmune diseases, lupus nephritis (LN) remains difficult to treat and is a significant cause of morbidity and mortality in lupus patients [3]. Treatment is currently guided by clinical presentation and histological classification but there are individual variations in disease course and treatment responses. It is not well understood why the severity and progression of the disease varies so widely [1].

Studies in murine LN models have helped to delineate some of the mechanisms of the human disease $[4,5]$, and to provide rationale to support clinical trials [6,7] but they only partially recapitulate events occurring in human LN. Unfortunately, genetically diverse humans do not always respond to treatment as well as observed in genetically restricted mouse strains. Improving our ability to predict disease course and follow treatment response is a crucial pre-requisite to improve efficacy and decrease toxicity of the current treatment protocols and define novel therapeutic targets.

The questions thus raised are: 1 . How can integration of the current knowledge about human LN and animal models provide more/new insights into the initiation of LN, its progression and its outcome? 2. Can the resulting information help to identify new biomarkers and therapeutic targets? To help answer these questions, systems biology has recently developed into a field that integrates complex biological information from the "omics" fields (genomics, transcriptomic, epigenetics, proteomics, metabolomics) with demographic, clinical or histologic parameters to provide a comprehensive description of regulatory events [8]. Defining the molecular mechanisms activated in individual patients may allow a personalized approach for the treatment and monitoring of LN. This review will show how, using current knowledge, the use of systems biology strategies might yield new insights into LN.

\section{LN mouse models}

One outcome of the explosion in genetic techniques for introducing or deleting single genes into mice is the realization that a large number of different single genetic defects can spontaneously give rise to lupus like manifestations, especially production of anti-nuclear antibodies and renal deposition of immune complexes [9]. This has led to the understanding that the causation of lupus is highly heterogeneous and can include defects in regulation of cell death, of innate immune cell or lymphocyte activation and of tissue responses to injury. Furthermore single genetic defects induce different outcomes in different mouse strains, emphasizing the effect of both susceptibility and resistance background genes on disease expression. Finally, disease in most of these models emerges with age, pointing to an important role for environmental exposures and stochastic factors in disease initiation. Similarly, in humans, a heterogeneous group of genetic polymorphisms is associated with SLE susceptibility [10] - whether some of these will have associations with particular disease manifestations including LN is yet to be determined.

Given the heterogeneity of disease course, outcome and response to therapy of $\mathrm{LN}$, even in those patients with comparable renal histology, and the lack of sequential biopsy material from humans, it remains essential to study informative animal models of disease [11]. Animal models of SLE nephritis offer the advantage that disease evolution can be studied in a timed manner and new therapies can be tested at various disease stages $[12,13]$. The mouse models fall into two broad categories, spontaneous and induced (summarized in Table 1). A few of the spontaneous murine LN models have been extensively studied. These classical models include the MRL/lpr and the BXSB. Yaa strains and the F1 hybrid between New Zealand Black (NZB)

*Corresponding author: Anne Davidson, Feinstein Institute for Medical Research, 350 Community Drive Manhasset, NY 11030, USA, Tel: 516562 3840; Fax: 516 562 2953; E-mail: adavidson1@nshs.edu

Received December 01, 2011; Accepted March 25, 2012; Published March 27 2012

Citation: Berthier CC, Kretzler M, Davidson A (2012) From the Large Scale Expression Analysis of Lupus Nephritis to Targeted Molecular Medicine. J Data Mining Genomics Proteomics 3: 123. doi:10.4172/2153-0602.1000123

Copyright: (c) 2012 Berthier CC, et al. This is an open-access article distributed under the terms of the Creative Commons Attribution License, which permits unrestricted use, distribution, and reproduction in any medium, provided the original author and source are credited. 
Citation: Berthier CC, Kretzler M, Davidson A (2012) From the Large Scale Expression Analysis of Lupus Nephritis to Targeted Molecular Medicine.

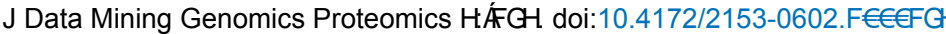

Page 2 of 7

\begin{tabular}{|c|c|c|c|c|c|c|c|c|}
\hline \multirow{3}{*}{$\begin{array}{l}\begin{array}{l}\text { Overall model } \\
\text { characteristic }\end{array} \\
\text { Model category } \\
\text { Model name }\end{array}$} & \multicolumn{5}{|c|}{ Diffuse proliferative glomerulonephritis } & \multirow{3}{*}{\begin{tabular}{|l}
$\begin{array}{l}\text { Proliferative } \\
\text { and interstitial } \\
\text { disease }\end{array}$ \\
Spontaneous \\
MRL/lpr \\
\end{tabular}} & \multirow{3}{*}{$\begin{array}{l}\begin{array}{l}\text { Sclerotic } \\
\text { glomerulo- } \\
\text { nephritis }\end{array} \\
\text { Spontaneous } \\
\text { NZM2410 }\end{array}$} & \multirow{3}{*}{$\begin{array}{l}\text { Induced } \\
\text { Nephrotoxic } \\
\text { nephritis }\end{array}$} \\
\hline & \multirow{2}{*}{$\begin{array}{l}\text { Spontaneous } \\
\text { NZB/W F1 hybrid } \\
\text { and NZM2328 }\end{array}$} & \multirow{2}{*}{$\begin{array}{l}\text { Spontaneous } \\
\text { SNF1 }\end{array}$} & \multirow{2}{*}{$\begin{array}{l}\text { Induced } \\
\text { Pristane induced } \\
\text { nephritis }\end{array}$} & \multicolumn{2}{|l|}{ Spontaneous } & & & \\
\hline & & & & BXSB.Yaa & NZW/BXSB & & & \\
\hline Antibodies & - Anti-dsDNA & - Anti-dsDNA & $\begin{array}{l}\text { - Anti-dsDNA } \\
\text { - Anti-chromatin } \\
\text { - Anti-Sm/RNP } \\
\text { - Anti-ribosomal } \\
\text { P }\end{array}$ & $\begin{array}{l}\text { - Anti-RNA } \\
\text { - Anti- } \\
\text { phospholipid }\end{array}$ & $\begin{array}{l}\text { - Anti-Sm/RNP } \\
\text { - Anti- } \\
\text { phospholipid }\end{array}$ & $\begin{array}{l}\text { - Anti-dsDNA } \\
\text { - Anti-ANA } \\
\text { - Anti-Sm } \\
\text { - Anti-ssDNA } \\
\text { - Anti-RNA } \\
\text { - Rheumatoid } \\
\text { factor }\end{array}$ & $\begin{array}{l}\text { - Anti-dsDNA } \\
\text { - Anti- } \\
\text { nucleosome }\end{array}$ & \\
\hline $\begin{array}{l}\text { Renal and non- } \\
\text { renal phenotype }\end{array}$ & $\begin{array}{l}\text { - Glomerular } \\
\text { enlargement + } \\
\text { hypercellularity } \\
\text { - T-cell, B-cell, } \\
\text { dendritic cell } \\
\text { accumulation } \\
\text { in perivascular } \\
\text { +periglomerular } \\
\text { aggregates } \\
\text { - Extensive } \\
\text { tubulo-interstitial } \\
\text { macrophage } \\
\text { infiltration }\end{array}$ & $\begin{array}{l}\text { - Glomerular } \\
\text { hypercellularity } \\
\text { - Thickening of } \\
\text { capillary loops } \\
+ \text { basement } \\
\text { membrane } \\
\text { - Mesangial } \\
\text { thickening } \\
\text { - Perivascular } \\
\text { infiltrates of } \\
\text { lymphoid cells } \\
\text { - Fibrosis }\end{array}$ & $\begin{array}{l}\text { - Mesangial and } \\
\text { subendothelial } \\
\text { deposits }\end{array}$ & $\begin{array}{l}\text { - Monocytosis } \\
\text { - Lymphoid } \\
\text { hyperplasia } \\
\text { - Circulating } \\
\text { immune } \\
\text { complexes }\end{array}$ & $\begin{array}{l}\text { - Large peri- } \\
\text { vascular } \\
\text { lymphoid } \\
\text { infiltrates } \\
\text { - Scattered } \\
\text { interstitial T cells } \\
\text { - Interstitial and } \\
\text { peri-glomerular } \\
\text { sheets of } \\
\text { macrophages } \\
\text { - Glomerular } \\
\text { dendritic cell } \\
\text { accumulation }\end{array}$ & $\begin{array}{l}\text { - Endothelial and } \\
\text { mesangial cell } \\
\text { proliferation } \\
\text { - Crescents } \\
\text { - Mononuclear } \\
\text { cell infiltrates - } \\
\text { accumulate even } \\
\text { when immune } \\
\text { complexes are } \\
\text { absent } \\
\text { - Renal vasculitis }\end{array}$ & $\begin{array}{l}\text { - Early podocyte } \\
\text { loss } \\
\text { - Interstitial } \\
\text { macrophage } \\
\text { accumulation } \\
\text { - Little } \\
\text { lymphocytic or } \\
\text { dendritic cell } \\
\text { infiltration }\end{array}$ & $\begin{array}{l}\text { - Acute neutrophil } \\
\text { and inflammatory } \\
\text { Gr1 }{ }^{\text {hi }} \text { macrophage } \\
\text { and T-cell } \\
\text { infiltration }\end{array}$ \\
\hline Other & & & & $\begin{array}{l}2 \text { active copies } \\
\text { expressed in } m\end{array}$ & $\begin{array}{l}\text { of TLR7 } \\
\text { ales }\end{array}$ & $\begin{array}{l}\text { - yIFN response } \\
\text { - Deficient in Fas }\end{array}$ & $\begin{array}{l}\cdot \text { IL-4 response } \\
\cdot \text { IgG1 + IgE } \\
\text { anti-chromatin } \\
\text { Abs }\end{array}$ & \\
\hline References & $\begin{array}{l}\text { - Schiffer et al, } \\
2008 \text { [29] } \\
\text { - Kalled et al, } 1998 \\
{[47]} \\
\text { - Jacob et al, } 2003 \\
{[48]}\end{array}$ & $\begin{array}{l}\text { • Kalled et al, } \\
1998 \text { [47] }\end{array}$ & $\begin{array}{l}\text { - Reeves et al, } \\
2009 \text { [18] }\end{array}$ & $\begin{array}{l}\text { - Atif et al, } \\
2006 \text { [49] } \\
\text { - Kimura et al, } \\
2011[50]\end{array}$ & $\begin{array}{l}\text { - Kahn et al, } \\
2008 \text { [51] }\end{array}$ & $\begin{array}{l}- \text { Singh et al, } \\
2003 \text { [52] } \\
\text { - Schwarting et } \\
\text { al, } 1998 \text { [53] } \\
\text { - Menke et al, } \\
2009 \text { [54] } \\
\cdot \text { Chan et al, } \\
1999 \text { [55] }\end{array}$ & $\begin{array}{l}\text { - Singh et al, } \\
2003 \text { [52] }\end{array}$ & $\begin{array}{l}\text { - Fu et al, } 2007 \\
\text { [19] } \\
\text { - Timoshanko et } \\
\text { al, } 2005 \text { [56] }\end{array}$ \\
\hline
\end{tabular}

Table 1: Commonly used murine LN models and characteristics.

and New Zealand White (NZW) and its inbred derivatives NZM2410 and NZM2328. These three models differ in the genetic causation of their disease. For example the MRL/lpr mouse is a strain with both permissive background genes and a complete deficiency of the Fas gene that is crucial for mediating lymphocyte cell death. The BXSB mouse has an extra copy of the TLR7 gene that mediates dendritic cell, mononuclear phagocyte and B lymphocyte activation after exposure to RNA antigens. NZB/W mice and their inbred derivatives have several genetic defects affecting lymphocyte activation that can mostly be reconstituted with 3 loci from different chromosomes. Although all three of these classic models develop LN, they differ in their gender bias, autoantibody profiles, clinical disease profiles and even in their renal pathology. Not surprisingly, striking differences in responses to immunologic interventions have been observed in these different mouse models [14-17] suggesting that multiple models will be needed to study responses to new therapies and to dissect pathogenetic mechanisms of $\mathrm{LN}$.

Induction of LN in susceptible mouse strains that do not spontaneously develop autoimmunity can be achieved by activation of the innate immune system using agents that induce Type I interferons (poly:IC, pristane) [18] or by artificial production of immune complexes that deposit in the kidneys (experimental nephrotoxic nephritis) [19]. The former group of models has been used to analyze the effects of genetic differences or interventions on disease initiation, while the latter has been used to examine markers of disease progression and the effects of genetic or treatment variables on tissue damage.
Each of these models is useful to study certain features of SLE but none can be considered a definitive model for testing mechanisms of pathogenesis or particular therapies. An understanding of the molecular features of these models that are shared with human disease will improve the ability to use these models effectively. A systems approach can help to define specific molecular characteristics of each of the mouse models, allowing the most representative model to be chosen for each molecular mechanism/research question of interest.

\section{LN models provide rationale for therapeutic trials}

Therapies for lupus have been tested in the spontaneous LN models and primarily target one of four major pathogenic pathways: innate immunity, B cells, T cells, and tissue injury/inflammation. These studies have led to several general findings that are relevant to the treatment of human disease. First, although mice with single gene deletions have been useful to study the role of critical molecules in disease initiation the findings are not always applicable to disease progression that is often promulgated by a different set of mechanisms and amplification pathways. Furthermore, some molecules are critical only in certain strains whereas others have pleiomorphic functions and therefore may be either protective or pathogenic depending on the disease stage. A second important lesson from mouse models is that many drugs are much more effective at preventing disease onset than at treating established disease and that as disease progresses higher drug doses and combination therapies are required to achieve remission. Importantly, different strains have different stringencies for therapeutic responses 
Citation: Berthier CC, Kretzler M, Davidson A (2012) From the Large Scale Expression Analysis of Lupus Nephritis to Targeted Molecular Medicine. J Data Mining Genomics Proteomics 3: 123. doi:10.4172/2153-0602.1000123

Page 3 of 7

\begin{tabular}{|c|c|c|c|c|c|}
\hline Reference & Species & Treatment study & Renal compartment & $\begin{array}{l}\text { Brief description } \\
\text { of the main results }\end{array}$ & $\begin{array}{l}\text { Correlation with } \\
\text { clinical/histological parameters }\end{array}$ \\
\hline $\begin{array}{l}\text { Peterson et al, } \\
2004 \text { (1) }\end{array}$ & Human & No. & $\begin{array}{l}\text { Glomerular } \\
\text { (laser-capture } \\
\text { microdissection) }\end{array}$ & $\begin{array}{l}\text { - Four main gene clusters of up-regulated } \\
\text { genes: } 1 \text {. Type I IFN-response element } \\
\text { genes; } 2 \text {. Myelomonocytic lineage and } \\
\text { inflammatory cell genes; } 3 \text {. B-cell genes; } 4 \text {. } \\
\text { ECM and glomerulosclerosis genes. } \\
\text { - One main cluster of down-regulated } \\
\text { genes included cellular growth, } \\
\text { differentiation, endothelial cell proliferation } \\
\text { and angiogenesis genes. }\end{array}$ & $\begin{array}{l}\text { There was a tendency for the genes } \\
\text { from the IFN-inducible gene cluster to be } \\
\text { associated with less crescent formation, } \\
\text { whereas transcripts from the B-cell } \\
\text { infiltration cluster were associated with more } \\
\text { crescents. }\end{array}$ \\
\hline $\begin{array}{l}\text { Liu et al, } \\
2006^{(2)}\end{array}$ & $\begin{array}{l}\text { MRL/lpr } \\
\text { mouse }\end{array}$ & No. & Whole kidneys & $\begin{array}{l}\text { Findings in this model recapitulated some } \\
\text { in humans: } \\
\text { - IFNy pathway members are dysregulated } \\
\text { and important in the development of LN in } \\
\text { this model. } \\
\text { - mRNA expression of genes implicated in } \\
\text { inflammatory pathways are also altered in } \\
\text { LN (e.g. cytokines, antigen presentation, } \\
\text {..) }\end{array}$ & Not done. \\
\hline $\begin{array}{l}\text { Teramoto et al, } \\
2008^{(3)}\end{array}$ & $\begin{array}{l}\text { MRL/lpr } \\
\text { mouse }\end{array}$ & $\begin{array}{l}\text { Yes. } \\
\text { (Prednisone) }\end{array}$ & $\begin{array}{l}\text { Glomerular } \\
\text { (laser-capture } \\
\text { microdissection) }\end{array}$ & $\begin{array}{l}\text { Findings in this model recapitulated some } \\
\text { in humans: } \\
\text { - Genes related to Th1 cells are up- } \\
\text { regulated (chemokines, chemokine } \\
\text { receptors, complement, coagulation, etc.). } \\
\text { IL-27 was highlighted. } \\
\text { - Effect of glucocorticoid treatment } \\
\text { (Prednisone): decrease of infiltrating } \\
\text { cell number, glomerular injury and } \\
\text { inflammatory gene expression. }\end{array}$ & Not done. \\
\hline $\begin{array}{l}\text { Reddy et al, } \\
2008^{(4)}\end{array}$ & $\begin{array}{l}\mathrm{NZB} / \mathrm{W} \\
\text { mouse }\end{array}$ & $\begin{array}{l}\text { Yes. } \\
\text { (Sirolimus) }\end{array}$ & Whole kidneys & $\begin{array}{l}\text { - } 387 \text { genes were regulated during LN, } \\
\text { associated with pathways such as antigen } \\
\text { presentation, complement, IL-1 and IL10 } \\
\text { signaling pathways, Jak-Stat and MAP } \\
\text { kinase pathways. } \\
\text { - Many of them were decreased after } \\
\text { treatment with the mTOR inhibitor } \\
\text { sirolimus. }\end{array}$ & Not done. \\
\hline $\begin{array}{l}\text { Bethunaickan } \\
\text { et al, } \\
2011^{(5)}\end{array}$ & NZB/W & $\begin{array}{l}\text { Yes. } \\
\text { (Cyclophosphamide + } \\
\text { CTLA4 Ig + anti-CD154 } \\
\text { Ab) }\end{array}$ & Renal F4/80 hi cells & $\begin{array}{l}\text { Activated renal macrophages contribute to } \\
\text { renal damage in LN: } \\
\text { - Transcripts from proinflammatory, } \\
\text { regulatory, tissue repair/degradation } \\
\text { pathways were overexpressed. } \\
\text { - Those transcripts were reduced to their } \\
\text { basal expression level after induction of } \\
\text { remission by immunosuppressive therapy. }\end{array}$ & Not done. \\
\hline
\end{tabular}

Table 2. Renal transcriptional profiling of LN in chronological order, as assessed by microarray studies.

and not all strains respond to each therapy [20]. Finally, mouse therapeutic studies are generally carried out with end stage renal failure as an endpoint and without standard of care therapies such as corticosteroids, hydroxychloroquine and immunosuppressive agents that themselves may have considerable therapeutic efficacy.

The studies in sum indicate that although animal studies provide valuable insights into the therapeutic potential of experimental drugs for SLE, additional considerations are needed when predicting the likely outcomes of treatments in human patients. This concept has been borne out by the results of human interventional studies. Therapies that are highly successful at disease prevention in some strains of mice, have either failed to show efficacy in a broad population of heterogeneous humans with active disease that are already receiving standard of care treatment (Rituxan) [21] or meet some defined clinical endpoints but not others (Abatacept) [22]. One potential advantage of a systems biology approach might be to define better therapeutic endpoints or therapeutic targets based on common gene expression patterns that reflect pathogenic mechanisms shared by most patients.

\section{LN biomarkers}

With the increasing recognition that SLE is a heterogeneous disease with variable causation, course and responsiveness to therapy there has been much interest in developing biomarkers for individualized disease management. Because it is difficult to obtain sufficient representative renal tissue and it is rare to obtain repeat biopsies from patients with LN there is a pressing need to define non-invasive markers of LN (plasma, serum, urine), which reflect either early renal molecular changes during disease or early responses to potentially toxic interventions. Types of biomarkers include quantification of soluble molecules or sets of molecules in serum or urine, gene expression profiles from peripheral blood cells or tissues, or functional assays of immune cell activation. These can then be correlated with clinical or histological phenotypes. Progress in biomarker development for SLE nephritis has been recently reviewed [23] and will therefore not be covered in detail here. Major challenges in biomarker development are the collection of reliable and reproducible longitudinal clinical data, optimal specimen collection, storage and data analysis. A systems approach may allow identification 
of more reliable biomarkers - recent examples of this approach include the development of strategies that group biomarkers into modules with predictive power [24,25].

\section{Systems Biology in The Context of LN}

Systems biology is a recent field which can be simply defined as "an opportunity to study how the phenotype is generated from the genotype" and as "the study of the behavior of complex biological organization and processes in terms of the molecular constituents" [26]. Various strategies integrating complex and large datasets of biological information are used, thus providing the power to comprehensively depict regulatory events. The potential of systems biology applied to the study of kidney diseases was recently described by John Cijiang He et al. [8] and in a special issue of the Seminars in Nephrology [27]. In short, powerful computational modeling is used to perform meta-analysis of the "omics" categories. As mentioned previously, integrating systems biology in LN has two major goals: the first is to characterize specific features in kidney, urine and/or blood which associate with known LN phenotypes so as to improve the understanding of LN renal regulatory events. The other is to identify new biomarkers and therapeutic targets.

Renal LN transcriptional signatures (using microarrays and realtime PCR) have been identified from humans and murine models and are summarized in Table 2. Renal compartments with the potential to reflect modifications of renal molecular mechanisms during LN include whole kidneys, subcompartments from microdissected kidneys, infiltrating renal cells and urine. Integration of information from diverse, independent sources provides confidence about which of the events happening in mouse are reproduced in humans and vice-versa. An ongoing challenge however, is the development of new methods to better integrate information from large-scale datasets. Using some of the transcriptomic studies presented in Table 2, we will show below how meta-analyses can integrate current knowledge about human and murine LN and open new doors for investigation.

\section{Cross-species LN renal transcriptional profiles: proof of concept}

We have recently shown that $\mathrm{F} 4 / 80^{\mathrm{hi}} / \mathrm{CD} 11 \mathrm{c}^{\mathrm{int}}$ intrinsic renal macrophages represent the major population of mononuclear phagocytic cells infiltrating the kidneys of nephritic NZB/W mice; these cells localize around glomeruli and throughout the renal interstitium [28]. Genome wide expression profile of $\mathrm{F} 4 / 80^{\text {hi }}$ cells extracted from NZB/W kidneys ("NZB/W dataset") demonstrated increased expression of inflammatory genes (e.g. ITGAM, CD40, C3), tissue remodeling genes (e.g. TIMP1, MMP-14) and anti-inflammatory genes (STAT3, PPARG, IL10) in nephritic compared to non-nephritic kidneys [28], highlighting the potential mechanisms by which these cells contribute to renal tissue damage. Using a stringent $q$ value of $<0.01$, a set of 378 genes were identified that were regulated in isolated $\mathrm{F} 4 / 80^{\text {hi }}$ cells from nephritic kidneys compared with young kidneys and whose expression pattern was reversed in kidneys of NZB/W mice in which remission of nephritis was induced with a combination of cyclophosphamide and costimulatory blockade [28,29]. These 378 genes reflect processes involved in pathogenesis and could also serve as potential disease biomarkers.

In human LN, renal mononuclear phagocyte infiltration is associated with poor disease outcome [30]. Therefore it is necessary to evaluate whether the activation of renal macrophages observed in NZB/W mice also occurs in human LN. Unfortunately the small amount of tissue available from renal biopsies obtained for clinical diagnostic purposes does not allow for isolation and analysis of cellular subpopulations as can be done in animal models. This is where integrative systems biology is useful. Currently, only one study, from Peterson et al., describes the transcriptional profiles of human LN laser-microdissected glomeruli compared to controls ("human dataset") [31]. This study identified 88 up-regulated and 89 down-regulated genes that were different between lupus and control glomeruli. In particular, they defined signatures of myelomonocytic and other inflammatory cells, extracellular matrix deposition and glomerulosclerosis.

To determine if the murine renal macrophage signature in LN can be also found in human LN glomeruli, we performed a cross-species comparison of the two datasets (NZB/W and human datasets). Two approaches were used:

1. The first strategy was to compare the genes differentially regulated both in isolated renal macrophages from nephritic compared with pre-diseased NZB/W mice and the human lupus glomeruli compared with normal controls. For this comparison we used a low stringency cut-off for the murine macrophage data to obtain the widest possible gene-set. Using a q value of $<0.05$ we found 1219 down and 1573 up-regulated genes in the macrophages from nephritic vs. pre-diseased NZB/W kidneys that also had a human gene ID. This list of genes was compared with the list of 177 genes representing the "human dataset". A total of 46 genes overlapped, of which 27 were regulated in the same direction in both datasets (22 upand 5 down-regulated) (Supplementary Table 1). These genes can be considered as representing a "glomerular macrophage signature" and, not surprisingly, were enriched for the "myeloid cluster" (12 genes) identified in the human study, including CTSB, ITGB2, LYN, HCK, CD40. Using Ingenuity Pathway Analysis software (IPA) to analyze the function of the 27 genes in the glomerular macrophage signature we identified several canonical pathways. "Fc $\gamma$ receptor-mediated phagocytosis in macrophages and monocytes" was the top canonical pathway. LYN and HCK, for example, are transcription factors that are important for $\mathrm{Fc}$ receptor mediated signaling that occurs downstream of immune complex stimulation of myeloid cells. "Integrin signaling" was the third regulated pathway. The integrin ITGB2 (CD18) is expressed on neutrophils, lymphocytes and macrophages and belongs to a family which mediates cell-cell and cell-matrix interactions in response to an inflammatory stimulus [32]. On macrophages it associates with ITGAM to form CD11b that is highly upregulated on F4/80 ${ }^{\text {hi }}$ cells in nephritic NZB/W kidneys. Thus myeloid cell activation with increased adhesion is a feature of the nephritic process. CTSB is a protease that is strongly expressed in normal renal tubules [33] and is upregulated in macrophages under inflammatory conditions where it plays a role in antigen processing and in cell death $[34,35]$.

2. The second strategy was to use the full human dataset derived from the two different human sample cohorts described by Peterson et al. [31] and apply a batch correction (using the Combat software [36]). Using the significance analysis of microarrays (SAM [37,38]), a total of 205 genes were regulated in human LN glomeruli compared to controls (q-value $<0.05)$, which were compared with the same 1219 down and 1573 upregulated genes from the nephritic compared to pre-diseased $\mathrm{NZB} / \mathrm{W}$ renal F4/80 ${ }^{\mathrm{hi}}$ macrophages [28]. 57 genes overlapped, which 38 regulated in the same direction in both datasets (31 up- 
A.

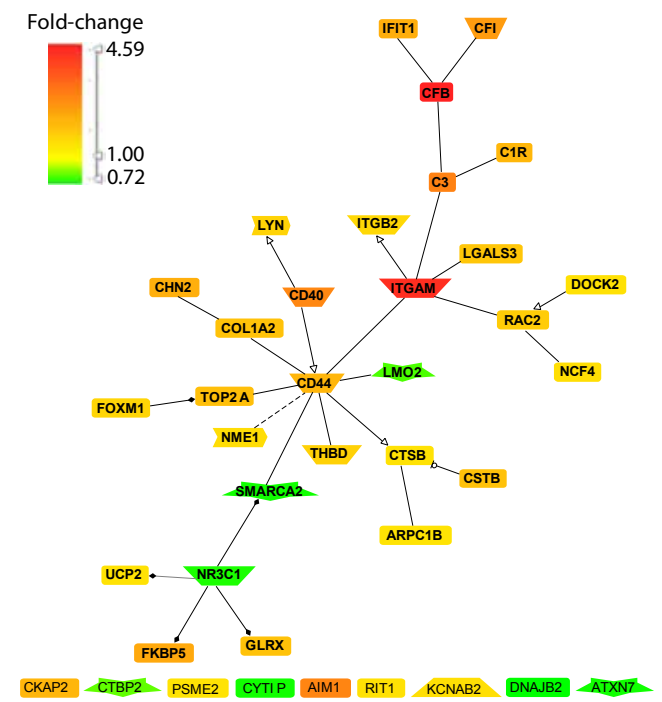

B.

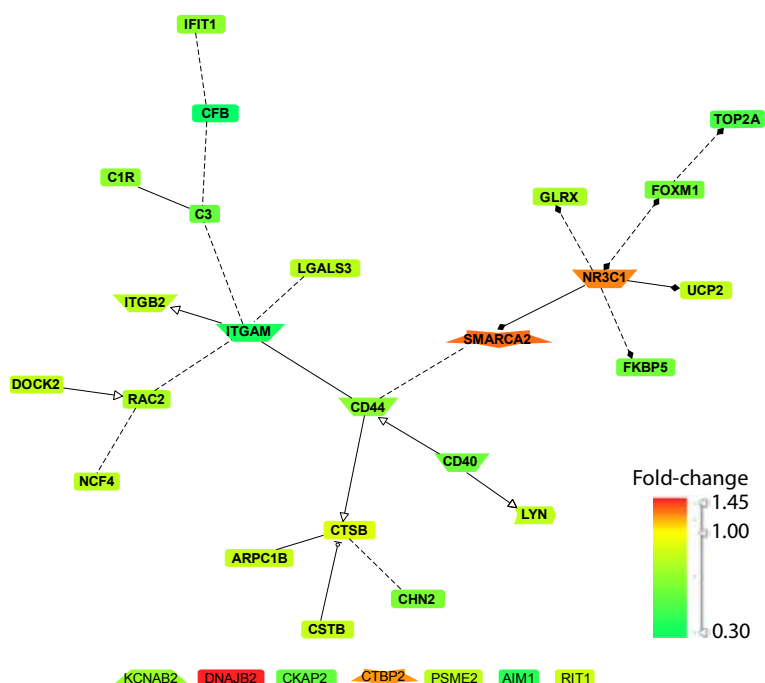

Legend

\begin{tabular}{|c|c|c|c|c|}
\hline$\square$ Protein & $\sum$ Kinase & ----- & $\begin{array}{l}2 \text { genes are associated by co-citation. } \\
2 \text { genes are associated by expert curation. }\end{array}$ & - Gene $A$ has a known transcription factor binding \\
\hline$\Longrightarrow R$ & $\approx c$ & & $\begin{array}{l}\text { Gene } A \text { activates gene } B \text {. } \\
\text { Gene A inhibits gene B. }\end{array}$ & \\
\hline
\end{tabular}

Figure 1: Genomatix Pathway System (GePS). A. Transcriptional network from the 38 LN "defined glomerular macrophage" genes. B. Transcriptional network from 31 of the 38 genes that had a reversed expression after induction of remission in murine LN. The picture displays the genes co-cited in PubMed abstracts in the same sentence. Colors represent the fold-change in the macrophages extracted from kidneys of nephritic mice compared to young mice.

and 7 down-regulated) representing nearly $20 \%$ of the regulated genes in the human glomerular samples (Supplementary Table 2). From these 38 genes, a transcriptional network was built using the Genomatix Pathway System (GePS) from Genomatix suite (Figure 1A) . This approach is based on all knowledge in the PubMed database and can identify functional interactions between proteins. CD44 and ITGAM represented major nodes. Complement system, integrin signaling and $\mathrm{Fc} \gamma$ receptormediated phagocytosis in macrophages and monocytes were the top canonical pathways from these 38 genes, using IPA software.

In our previous study, we showed that a significant proportion of the defined transcriptional LN murine renal macrophage signature was reversed after induction of remission [28]. We therefore asked whether the genes constituting the reversible renal macrophage phenotype observed in LN mouse kidneys could be potentially targeted in human $\mathrm{LN}$ as well. To answer this question, the regulation of the 38 genes characterizing the "glomerular macrophage transcriptional signature" was analyzed in the $\mathrm{F} 4 / 80^{\mathrm{hi}}$ cells from kidneys of mice after remission induction (Figure 1B). The expression of 31 genes was reversed (27 down-regulated and 4 up-regulated). These 31 genes, that include CTSB, complement components, ITGAM, CD40, CD44 and IFIT1, could thus be potential human LN biomarkers or therapeutic targets.

Identification of new biomarkers in human LN may be achieved by linking genome wide expression data to clinical and/or histological available parameters. To illustrate this approach, we correlated the mRNA expression of the 31 defined genes described above with GFR, serum creatinine and degree of proteinuria (Supplementary Table 3). As an example, C3 was the top mRNA correlating with GFR-MDRD, it also correlated with serum creatinine and proteinuria. In addition, the higher the score of monocytes in human LN glomeruli (CD68), the higher were the mRNA expression of C3 and CTSB (Supplementary Figure 1).

In summary, cross-species transcriptomic analysis using a systems biology approach allowed us to show that expression of several LN murine macrophage inflammatory transcripts was recapitulated in human LN glomeruli. These findings show the high representation of macrophage derived genes in the glomerular inflammatory signature in human LN. The findings suggest the importance of immune complexes in activating renal infiltrating macrophages via $\mathrm{Fc}$ receptors in humans as described in murine models [39]. These findings also emphasize the role of integrin signaling, most likely through CD11b and of the alternative complement activation pathway in the inflammatory response.

We identified 38 genes constituting a "glomerular macrophage transcriptional signature". The function of the corresponding proteins and their role as potential therapeutic targets can now be fully evaluated in the appropriate murine model. Another useful step is to determine whether increased expression of the mRNAs that participate in the inflammatory events of LN kidneys through macrophage infiltration/ activation could be used as non-invasive markers to detect nephritis onset or therapeutic response earlier. A way to do this is to search for expression of known macrophage genes in PBMCs or urine pellets of nephritic vs. non-nephritic SLE patients or in patients before and after 
remission induction. This hypothesis can now be tested using available PBMC expression databases or in the context of SLE nephritis clinical trials.

\section{Integration of transcriptional regulation with genetic predisposition and vice-versa}

As an unbiased screening tool, GWAS have the potential to discover novel causative associations with human diseases. Understanding the genetic components of human SLE and their involvement in the disease is currently a promising area of biomedical research [40,41]. A rapidly growing list of genes and loci has been shown to confer susceptibility for SLE [10]. A major challenge is the integration of these genetic associations into biological knowledge of the multifaceted disease pathogenesis. This is particularly relevant for SLE as the disease affects the entire organism on multiple levels with interrelated pathways. To understand the complexity of the disease process in the SLE patient an integrative analysis of regulatory cascades is essential.

Using a systems biology approach, genes identified in genome wide association studies (GWAS) can be integrated into their functional disease context; these studies should help to prioritize genes for fine mapping and further functional studies. This approach has been reviewed recently in the context of chronic kidney disease [42]. As proof of concept, a recent study identified three miRNAs that together are predicted to target over $50 \%$ of 72 lupus susceptibility genes $[43,44]$. These early studies will require confirmation but have potential functional and therapeutic implications.

The converse hypothesis is also a promising approach. Indeed, linking genome wide mRNA expression with genome wide association studies (GWAS) may provide a good starting point to define new LN associated genes. An elegant proof of concept study in the anti-GBM murine model of LN identified an association of the disease susceptibility with the repression of kallikrein transcripts in kidneys [45]. This study showed that the bradykinin $\mathrm{B} 2$ receptor mediated the biological effects of decreased kallikreins and that glomerulonephritis was aggravated by its blockage. Conversely, bradykinin administration improved the disease in susceptible mice. This result motivated the analysis of the orthologous locus in LN patients, leading to the identification of single polymorphisms (SNPs) in the sequence of kallikrein 1 and 3 promoters that are strongly associated with LN.

A final example of how integrative systems biology can be a powerful tool in the context of LN is Nephromine (http://www.nephromine.org), a free available resource integrating all available renal genome wide expression data (e.g. Peterson's human dataset [31]), to improve the understanding of the renal molecular events associated with normal function and disease.

\section{Conclusions}

Systems biology allows the identification of regulatory transcriptional cascades. This can be reinforced by the study of transcription factor interactions and the identification of their transcriptional targets, thanks to the current bioinformatics tools that are available [46]. As we have shown here, profiling of renal tissues and other compartments can be linked together, to provide new information about genes and pathways implicated in the pathogenesis of LN. As more datasets become available, future deep analysis of the "Omics" of lupus nephritis using systems biology will be a powerful tool in the path to targeted molecular medicine.

\section{References}

1. Rahman A, Isenberg DA (2008) Systemic lupus erythematosus. N Engl J Med 358:929-939.

2. Schwartz MM (2007) The pathology of lupus nephritis. Semin Nephrol 27: 22 34.

3. Adalid-Peralta L, Mathian A, Tran T, Delbos L, Durand-Gasselin I, et al. (2008) Leukocytes and the kidney contribute to interstitial inflammation in lupus nephritis. Kidney Int 73: 172-180.

4. Reddy PS, Legault HM, Sypek JP, Collins MJ, Goad E, et al. (2008) Mapping similarities in mTOR pathway perturbations in mouse lupus nephritis models and human lupus nephritis. Arthritis Res Ther 10: R127.

5. Ponticelli C, Meroni PL (2009) Kallikreins and lupus nephritis. J Clin Invest 119: 768-771.

6. Kitching AR (2005) More targeted treatments for lupus nephritis: is the future (nearly) here? J Am Soc Nephrol 16: 3146-3148.

7. Bagavant H, Kalantarinia K, Scindia Y, Deshmukh U (2011) Novel therapeutic approaches to lupus glomerulonephritis: translating animal models to clinical practice. Am J Kidney Dis 57: 498-507.

8. He JC, Chuang PY, Ma'ayan A, Lyengar R (2011) Systems biology of kidney diseases. Kidney Int 81: 22-39.

9. Subramanian S, Tus K, Li QZ, Wang A, Tian XH, et al. (2006) A TIr7 translocation accelerates systemic autoimmunity in murine lupus. Proc Nat Acad Sci USA 103: 9970-9975

10. Criswell LA (2008) The genetic contribution to systemic lupus erythematosus Bull NYU Hosp Jt Dis 66: 176-183.

11. Grande JP (2011) Experimental models of lupus nephritis. Contrib Nephro 169: 183-197.

12. Ramanujam M, Davidson A (2008) Targeting of the immune system in systemic lupus erythematosus. Expert Rev Mol Med 10: e2.

13. Davidson A, Aranow C (2010) Lupus nephritis: lessons from murine models Nat Rev Rheumatol 6: 13-20

14. Clynes R, Dumitru C, Ravetch JV (1998) Uncoupling of immune complex formation and kidney damage in autoimmune glomerulonephritis. Science 279 1052-1054.

15. Matsumoto K, Watanabe N, Akikusa B, Kurasawa K, Matsumura R, et al. (2003) Fc receptor-independent development of autoimmune glomerulonephritis in lupus-prone MRL/lpr mice. Arthritis Rheum 48: 486-494.

16. Ehlers M, Fukuyama H, McGaha TL, Aderem A, Ravetch JV (2006) TLR9/ MyD88 signaling is required for class switching to pathogenic $\lg \mathrm{G} 2 \mathrm{a}$ and $2 \mathrm{~b}$ autoantibodies in SLE. J Exp Med 203: 553-561.

17. Wu X, Peng SL (2006) Toll-like receptor 9 signaling protects against murine lupus. Arthritis Rheum 54: 336-342.

18. Reeves WH, Lee PY, Weinstein JS, Satoh M, Lu L (2009) Induction of autoimmunity by pristane and other naturally occurring hydrocarbons. Trends Immunol 30: 455-464.

19. Fu Y, Du Y, Mohan C (2007) Experimental anti-GBM disease as a tool for studying spontaneous lupus nephritis. Clin Immunol 124:109-118.

20. Moisini I, Davidson A (2009) BAFF: a local and systemic target in autoimmune diseases. Clin Exp Immunol 158: 155-163.

21. Merrill JT, Neuwelt CM, Wallace DJ, Shanahan JC, Latinis KM, et al. (2010) Efficacy and safety of rituximab in moderately-to-severely active systemic lupus erythematosus: the randomized, double-blind, phase II/III systemic lupus erythematosus evaluation of rituximab trial. Arthritis Rheum 62: 222-233.

22. Dall'Era M, Wofsy D (2010) Biologic therapy for systemic lupus erythematosus Discov Med 9: 20-23.

23. Mok CC (2010) Biomarkers for lupus nephritis: a critical appraisal. J Biomed Biotechnol 2010: 638413.

24. Bauer JW, Bilgic $\mathrm{H}$, Baechler EC (2009) Gene-expression profiling in rheumatic disease: tools and therapeutic potential. Nat Rev Rheumatol 5: 257-265.

25. Chaussabel D, Quinn C, Shen J, Patel P, Glaser C, et al. (2008) A modular analysis framework for blood genomics studies: application to systemic lupus erythematosus. Immunity 29: 150-164. 
Citation: Berthier CC, Kretzler M, Davidson A (2012) From the Large Scale Expression Analysis of Lupus Nephritis to Targeted Molecular Medicine. J Data Mining Genomics Proteomics 3: 123. doi:10.4172/2153-0602.1000123

26. Kirschner MW (2005) The meaning of systems biology. Cell 121: 503-504

27. Kretzler M, Cohen CD (2010) Integrative biology of renal disease: toward a holistic understanding of the kidney's function and failure. Semin Nephrol 30: 439-442.

28. Bethunaickan R, Berthier CC, Ramanujam M, Sahu R, Zhang W, et al. (2011) A unique hybrid renal mononuclear phagocyte activation phenotype in murine systemic lupus erythematosus nephritis. J Immunol 186: 4994-5003.

29. Schiffer L, Bethunaickan R, Ramanujam M, Huang W, Schiffer M, et al. (2008) Activated renal macrophages are markers of disease onset and disease remission in lupus nephritis. J Immunol 180: 1938-1947.

30. Hill GS, Delahousse M, Nochy D, Remy P, Mignon F, et al. (2001) Predictive power of the second renal biopsy in lupus nephritis: significance of macrophages. Kidney Int 59: 304-316.

31. Peterson KS, Huang JF, Zhu J, D'Agati V, Liu X, et al. (2004) Characterization of heterogeneity in the molecular pathogenesis of lupus nephritis from transcriptional profiles of laser-captured glomeruli. J Clin Invest 113: 1722-1733.

32. Hicks J, Bullard DC (2006) Review of autoimmune (lupus-like) glomerulonephritis in murine models. Ultrastruct Pathol 30: 345-359.

33. Howie AJ, Burnett D, Crocker J (1985) The distribution of cathepsin B in human tissues. J Pathol 145: 307-314.

34. Kominami E, Tsukahara T, Bando Y, Katunuma N (1985) Distribution of cathepsins $\mathrm{B}$ and $\mathrm{H}$ in rat tissues and peripheral blood cells. J Biochem 98 : $87-93$.

35. Ostensen M, Morland B, Husby G (1983) Stimulation of murine macrophage cathepsin $B$ by serum from patients with rheumatoid arthritis: an indicator of disease activity. Clin Exp Immunol 51: 103-109.

36. Johnson WE, Li C, Rabinovic A (2007) Adjusting batch effects in microarray expression data using empirical Bayes methods. Biostatistics 8: 118-127.

37. Saeed Al, Sharov V, White J, Li J, Liang W, et al. (2003) TM4: a free, opensource system for microarray data management and analysis. Biotechniques 34: $374-378$

38. Saeed AI, Bhagabati NK, Braisted JC, Liang W, Sharov V, et al. (2006) TM4 microarray software suite. Methods Enzymol 411: 134-193.

39. Bergtold A, Gavhane A, D'Agati V, Madaio M, Clynes R (2006) FcR-bearing myeloid cells are responsible for triggering murine lupus nephritis. J Immunol 177:7287-7295.

40. Gutierrez-Roelens I, Lauwerys BR (2008) Genetic susceptibility to autoimmune disorders: clues from gene association and gene expression studies. Curr Mol Med 8: 551-561.

41. Lettre G, Rioux JD (2008) Autoimmune diseases: insights from genome-wide association studies. Hum Mol Genet 17: R116-R121.

42. Keller BJ, Martini S, Sedor JR, Kretzler M (2011) A systems view of genetics in chronic kidney disease. Kidney Int 81: 14-21.

43. Te JL, Dozmorov IM, Guthridge JM, Nguyen KL, Cavett JW, et al. (2010)
Identification of unique microRNA signature associated with lupus nephritis. PLoS One 5: e10344.

44. Dai $Y$, Sui W, Lan H, Yan Q, Huang H, Huang Y (2009) Comprehensive analysis of microRNA expression patterns in renal biopsies of lupus nephritis patients. Rheumatol Int 29: 749-754.

45. Liu K, Li QZ, Delgado-Vega AM, Abelson AK, Sanchez E, et al. (2009) Kallikrein genes are associated with lupus and glomerular basement membrane-specific antibody-induced nephritis in mice and humans. J Clin Invest 119: 911-923.

46. Werner T, Fessele S, Maier H, Nelson PJ (2003) Computer modeling of promoter organization as a tool to study transcriptional coregulation. FASEB J 17: 1228-1237

47. Kalled SL, Cutler AH, Datta SK, Thomas DW (1998) Anti-CD40 ligand antibody treatment of SNF1 mice with established nephritis: preservation of kidney function. J Immunol 160: 2158-2165.

48. Jacob CO, Zang S, Li L, Ciobanu V, Quismorio F, et al. (2003) Pivotal role of Stat 4 and Stat 6 in the pathogenesis of the lupus-like disease in the New Zealand mixed 2328 mice. J Immunol 171: 1564-1571.

49. Atif AA, Olcay YJ (2009) Renal pathology and morphometric studies on natura history of BXSB lupus mice. FASEB J Meeting abstract supplement, 1004.2.

50. Kimura J, Ichii O, Otsuka S, Kanazawa T, Namiki Y, et al. (2011) Quantitative and qualitative urinary cellular patterns correlate with progression of murine glomerulonephritis. Plos One 6: e16472.

51. Kahn P, Ramanujam M, Bethunaickan R, Huang W, Tao H, et al. (2008) Prevention of murine antiphospholipid syndrome by BAFF blockade. Arthritis Rheum 58: 2824-2834.

52. Singh RR, Saxena V, Zang S, Li L, Finkelman FD, Witte DP, Jacob CO (2003) Differential contribution of IL-4 and Stat6 vs Stat 4 to the development of lupus nephritis. J Immunol 170: 4818-4825.

53. Schwarting A, Wada T, Kinoshita K, Tesch G, Kelley VR (1998) IFN-gamma receptor signaling is essential for the initiation, acceleration, and destruction of autoimmune kidney disease in MRL-Fas(Ipr) mice. J Immunol 161: 494-503.

54. Menke J, Rabacal WA, Byrne KT, Iwata Y, Schwartz MM, et al. (2009) Circulating CSF-1 promotes monocyte and macrophage phenotypes that enhance lupus nephritis. J Am Soc Nephrol 20: 2581-2592.

55. Chan OT, Hannum LG, Haberman AM, Madaio MP, Shlomchik MJ (1999) A novel mouse with $B$ cells but lacking serum antibody reveals an antibodyindependent role for B cells in murine lupus. J Exp Med 189: 1639-1648.

56. Timoshanko JR, Tipping PG (2005) Resident kidney cells and their involvement in glomerulonephritis. Curr Drug Targets Inflamm Allergy 4: 353-362.

57. Liu J, Karypis G, Hippen KL, Vegoe AL, Ruiz P, et al. (2006) Genome view of systemic autoimmunity in MRLIpr mice. Genes Immun 7: 156-168.

58. Teramoto K, Negoro N, Kitamoto K, Iwai T, Iwao H, et al. (2008) Microarray analysis of glomerular gene expression in murine lupus nephritis. J Pharmaco Sci 106: 56-67.
Submit your next manuscript and get advantages of OMICS Group submissions

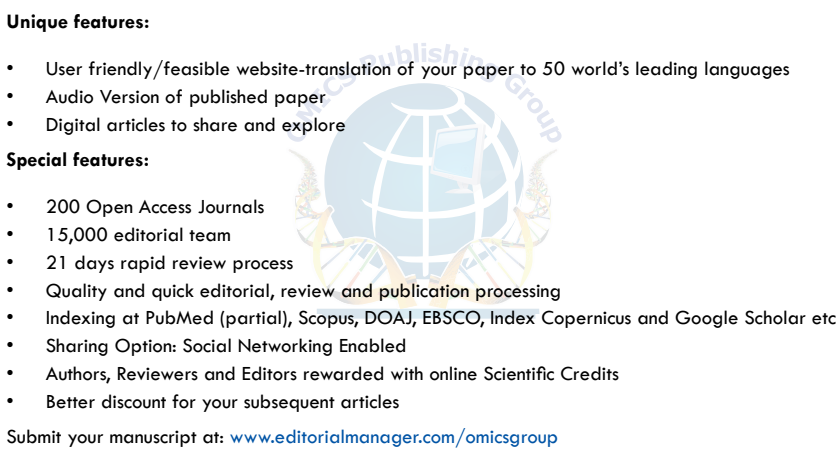

